\title{
Microbial desulphurization of coal containing pyritic sulphur in a continuously operated bench scale coal slurry reactor
}

\author{
R.A. Pandey*, V.K. Raman, S.Y. Bodkhe, B.K. Handa, A.S. Bal \\ National Environmental Engineering Research Institute, Nehru Marg, Nagpur 440 020, India
}

Received 5 November 2003; accepted 6 July 2004

Available online 20 August 2004

\begin{abstract}
Pre-combustion microbial desulphurization of coal containing total sulphur (3.90\%) and pyritic sulphur (2.80\%) has been evaluated in a coal slurry reactor. The coal slurry reactor operated at hydraulic retention time (HRT) of $96 \mathrm{~h}$ with a coal pulp density of 15 percent and remove 79 percent of pyritic sulphur and 76 percent of ash with an increase in the calorific value of coal from 4400 to $6800 \mathrm{kcal} \mathrm{kg}^{-1}$ at a pyritic load of $1.9 \mathrm{~kg}$ pyritic sulphur $\mathrm{kg}^{-1}$ MLSS d $\mathrm{d}^{-1}$. The treated coal yield is 72 percent. The biochemical kinetic coefficients, viz. yield coefficient $(Y)$ and decay coefficient $\left(K_{\mathrm{d}}\right)$ in the coal slurry reactor system are 0.178 and $0.007 \mathrm{~d}^{-1}$, respectively, while maximum growth rate $\left(\mu_{\max }\right)$ and half saturation rate constant $\left(K_{\mathrm{s}}\right)$ are $0.025 \mathrm{~h}^{-1}$ and $0.220 \mathrm{~g} \mathrm{l^{-1 }}$ as pyrite, respectively.

(C) 2004 Elsevier Ltd. All rights reserved.
\end{abstract}

Keywords: Microbial desulphurizatoin; Pyritic sulphur; Coal slurry reactor; Thiobacillus ferrooxidans; Thiobacillus thiooxidans

\section{Introduction}

Direct combustion of coal containing high pyritic sulphur and ash results in several environmental problems, viz. emission of oxides of sulphur, acid rain and low recovery of heat energy from coal with formation of excess ash as solid waste. The sulphur dioxide has deleterious effect on human, animal, and plant life [1]. To eliminate the pollution problem caused by the sulphur present in coal, precombustion desulphurization of coal is essential [1].

Several physico-chemical precombustion desulphurization processes, for coal have, been reported in the literature, viz. floatation, oxidation, and reduction with chemicals. Precombustion microbial desulphurization of coal is yet another process using microbial entities in controlled conditions [2,3]. Mesophillic, moderately thermophilic and extremely thermophilic microorganisms exhibit the ability to enhance pyrite oxidation and

\footnotetext{
* Corresponding author. Tel.: +91-712-222-725.

E-mail address: rapandey @ hotmail.com (R.A. Pandey).
}

solubilization. Moreover, the mesophiles seem to be the most suitable for development of a commercial process for precombustion microbial desulphurization of coal [4-6].

On the bench scale several types of reactor systems, viz. packed bed, air lift bioreactor, plug flow reactor, conventional stirred tank reactor, etc. have been studied for removal of pyrite sulphur from coal [7]. Microbial removal rate of pyritic sulphur from coal in different bioreactors varied widely, due to improper interaction of coal particles containing pyrite and the microorganisms, achieving the desired level of dissolved oxygen in the bioreactor system and lack of information on kinetic parameters [7-11]. The present paper outlines the work carried out on microbial desulphurization of coal containing high pyritic sulphur, on bench scale, using a coal slurry reactor and Thiobacillus ferrooxidans ${ }^{\mathrm{AM}}$ and Thibacillus thiooxidans ${ }^{\mathrm{AM}}$ mixed biomass as a starter seed. Kinetic co-efficients, viz. yield-coefficient $(Y)$, decay co-efficient $\left(K_{\mathrm{d}}\right)$, half saturation rate constant $\left(K_{\mathrm{s}}\right)$, and maximum growth rate constant $\left(\mu_{\max }\right)$ have also been evaluated for the system. 


\begin{tabular}{|c|c|}
\hline \multicolumn{2}{|l|}{ Notations } \\
\hline $\begin{array}{ll}\operatorname{HRT}(\theta) & \text { hydraulic retention time } \\
Y & \text { yield coefficient }\end{array}$ & $\begin{array}{l}\text { expressed as Mixed Liquor Suspended Solids } \\
\text { (MLSS) }\end{array}$ \\
\hline$K_{\mathrm{d}} \quad$ decay coefficient, $\mathrm{d}^{-1}$ & So (wt\%) Initial concentration of pyritic sulphur in coal \\
\hline $\begin{array}{ll}\left(\mu_{\max }\right) & \text { maximum growth rate } \\
K_{\mathrm{s}} & \text { half saturation rate constant, } \mathrm{h}^{-1}\end{array}$ & $\begin{array}{l}S(\text { wt } \%) \text { Concentration of pyritic sulphur in coal after } \\
\text { desulphurization }\end{array}$ \\
\hline sludge retention time, $\mathrm{d}$ & per day \\
\hline $\begin{array}{l}\text { concentration of biomass in the reactor, } \\
\text { (in terms of protein } \mathrm{mg} \mathrm{l}^{-1} \text { and also }\end{array}$ & Loading, $\mathrm{kg}$ pyretic sulphur $\mathrm{kg}^{-1} \mathrm{MLSS} \mathrm{d}^{-1}$ \\
\hline
\end{tabular}

\section{Experimental}

\subsection{Coal samples}

The coal samples collected from Rajur coal mines, Wardha region in India were characterized using standard procedures [12] and were used for microbial desulphurization, for removal of pyritic sulphur. A pulverized coal sample containing particle size in the range of $45-65 \mu \mathrm{m}$ was used in the experiments.

\subsection{Bioreactor}

The bioreactor was a coal slurry reactor of rectangular shape with a working volume of 601 and made up of perspex sheet. The schematic diagram of the bench scale unit is presented in Fig. 1. The bioreactor was attached to a separate settler, of 2.51 working capacity with rectangular in shape having tapering end and also made up of perspex sheet. Pumps were used for feeding the nutrient medium and recirculation of the overflow liquid from settler, at a controlled flow rate. The overflow of the settler was collected in a reservoir. A portion of collected overflow was recirculated back into the reactor, which helps in maintenance of microorganisms in the bioreactor. The bioreactor was fitted with an aerator cum mixer, which operates at a constant speed. The bench scale coal slurry reactor also consisted of a coal feeding device which works on the principle of screw based pushing system to maintain the required pulp density and different loads of sulphur systems in the bioreactor.

\subsection{Nutrient medium and microorganisms}

Ammonium chloride $\left(0.4 \mathrm{~g} \mathrm{l}^{-1}\right)$, dipottasium hydrogen phosphate $\left(0.4 \mathrm{~g} \mathrm{l}^{-1}\right)$ and magnesium chloride $\left(0.4 \mathrm{~g} \mathrm{l}^{-1}\right)$ were added to the bioreactor as nutrients, while sulphuric acid $\left(0.9 \mathrm{mg} \mathrm{l}^{-1}\right)$ was added for adjusting the $\mathrm{pH}$ to $2.4 \pm 0.2$ of the reactor system. All the experiments were carried out at a temperature of $32 \pm 2{ }^{\circ} \mathrm{C}$. Mixed cultures of T. ferrooxidans ${ }^{\mathrm{AM}}$ and T. thiooxidans ${ }^{\mathrm{AM}}$ were used for desulphurization of coal. These cultures were isolated from sediments of a river which flows through a coal belt containing high sulphur. Isolated cultures were stored and maintained on a nutrient medium with coal containing sulphur.

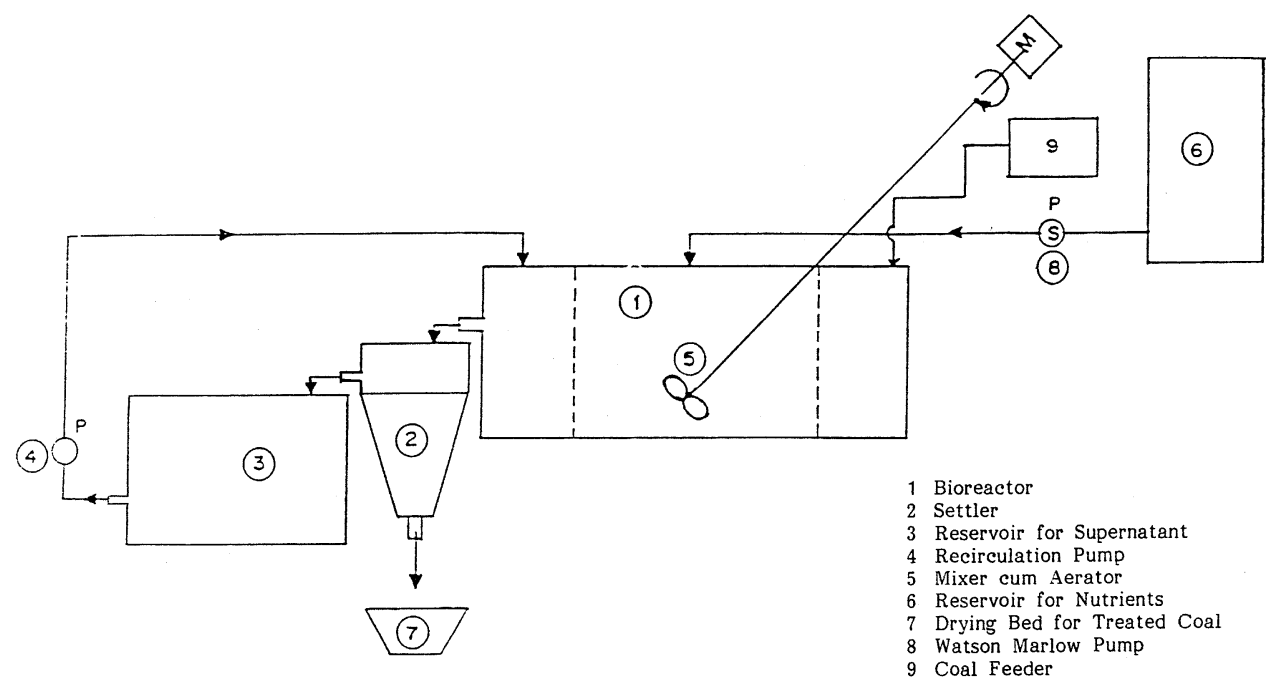

Fig. 1. Flow diagram of a coal slurry reactor for pyritic sulphur removal from coal. 


\subsection{Methods}

\subsubsection{Development of biomass in the reactor}

The biomass of the bioreactor was developed by fill and draw method and increase in the biomass at each step was measured by indirect method of estimating the protein [13]. When a biomass concentration of $300 \mathrm{mg} / \mathrm{l}$ was achieved, the continuous feeding of coal and nutrient medium was resumed.

\subsubsection{Assessment of hydraulic retention time at fixed pulp density}

The performance of the coal slurry bioreactor was evaluated at various hydraulic retention times (HRTs) by manipulating the feed volume at a fixed pulp density of $10 \%$. Five sets of data for each HRT were collected and evaluated, when the system started operating at a pseudosteady state, with reference to the level of biomass concentration in the reactor and uniform quality of the treated coal.

\subsubsection{Evaluation of pulp density at optimal HRT}

Performance evaluation of the coal slurry was carried out at various pulp densities of coal, ranging from 5 to 40 percent (percent of coal weight $/ 100 \mathrm{ml}$ of medium). Five sets of observations were made at each pulp density at pseudo-steady state of the operation. During the investigations, sulphur content, proximate analysis and calorific value of coal were estimated by standard procedures.

\subsubsection{Assessment of sulphur loading in the coal slurry reactor at optimal $H R T$}

The performance of coal slurry reactor was evaluated at different total sulphur loadings in the range of $16-1.78 \mathrm{~kg}$ total sulphur $\mathrm{kg}^{-1} \mathrm{MLSS} \mathrm{d}^{-1}$. The sulphur loading in terms of pyritic sulphur was in the range of $1.1-11.3 \mathrm{~kg}$ pyritic sulphur $\mathrm{kg}^{-1} \mathrm{MLSS}^{-1}$. This could be achieved by manipulating the feed weight of the coal to the bioreactor system.

\section{Results and discussion}

\subsection{Characteristics of coal}

Results indicate that the coal sample, under investigation, contains high ash (31\%) and sulphur (3.9\%). Most of the sulphur present in the coal is in the form of pyrite $(2.8 \%)$. It has been well recognised that the pyrite molecule is cubic, with the octahedrally coordinated metal atoms at the corner and face centres of the cubic cell [14]. The interpretation of leaching and bioleaching behaviour of pyrite in the light of arrangement of disulphide item and its other properties help in prediction of possibilities for microbial removal of pyrite from coal $[14,15]$.

\subsection{Microbial desulphurization of coal containing pyritic sulphur}

Microbial desulphurization of coal containing pyrite results in the oxidative conversion of iron disulphide into a water soluble product viz ferric sulphate. The pyrite removal from coal results from direct combined effects of $T$. ferrooxidan and T. thiooxidan and indirect chemical solubilization [4]. The two species seem to compete and cooperate simultaneously. These microorganisms form an efficient system in which the main reactants (cell, $\mathrm{Fe}^{3+}$, $\mathrm{H}^{+}$) are self-regenerating and only oxygen, carbon dioxide and trace nutrients need to be supplemented [13].

\subsection{Performance evaluation of coal slurry reactor at various HRTs}

The operating conditions of coal slurry reactor at various HRTs are presented in Table 1 . The coal slurry reactor was operated at HRTs ranging from 24 to $144 \mathrm{~h}$. The results indicate that a HRT of $96 \mathrm{~h}$ (4 days) is observed to be optimal which resulted in 78-81 percent removal of sulphur from the coal. Further increase in the HRT did not result in appreciable improvement of the efficiency with respect to the removal of sulphur and ash (Fig. 2). Other worker have cited that the optimal HRT for slurry reactor system for microbial desulphurization of coal containing pyrite in the ranges of 9-28 days [10-12,14]. The present findings indicate that the coal slurry reactor operated for removal of pyrite using indigenously isolated mixed cultures of T. ferrooxidans ${ }^{\mathrm{AM}}$ and T. thiooxidans ${ }^{\mathrm{AM}}$ showed better efficiency of pyritic sulphur removal as compared to the reports cited in literature [10,11,14-17]. A HRT of more than 7 days resulted in buildup of inhibitory products in the coal slurry reactor system, resulting in poor performance of microbial desulphurization of coal and appears to be feasible on a laboratory scale. The use of coal-water

Table 1

Operational details of coal slurry reactor for microbial desulphurization of coal containing high pyritic sulphur

\begin{tabular}{|c|c|c|c|c|c|}
\hline \multicolumn{6}{|l|}{ Details of the reactor } \\
\hline \multicolumn{4}{|c|}{ Working volume of the reactor (1) } & \multicolumn{2}{|c|}{601} \\
\hline \multicolumn{4}{|c|}{ Coal particle size $(\mu \mathrm{m})$} & \multicolumn{2}{|c|}{$45-65$} \\
\hline \multicolumn{4}{|c|}{ Pulp density (\% $100 \mathrm{ml}^{-1}$ ) } & \multicolumn{2}{|c|}{10} \\
\hline \multicolumn{6}{|c|}{ Working conditions at different HRTs } \\
\hline & \multicolumn{5}{|c|}{ Days } \\
\hline & 1 & 2 & 3 & 4 & 6 \\
\hline Feed volume $\left(\mathrm{L} \mathrm{d}^{-1}\right)$ & 60 & 30 & 20 & 15 & 10 \\
\hline Coal feeding $\left(\mathrm{kg} \mathrm{d}^{-1}\right)$ & 6 & 3 & 2 & 1.5 & 1 \\
\hline $\begin{array}{l}\text { Biomass in the reactor } \\
\left(\mathrm{mg} \mathrm{l}^{-1} \text { as protein) }\right.\end{array}$ & 250 & 278 & 306 & 351 & 450 \\
\hline $\begin{array}{l}\text { Biomass in the Effluent } \\
\left(\mathrm{mg} \mathrm{l}^{-1}\right)\end{array}$ & 165 & 107 & 50 & 68 & 50 \\
\hline
\end{tabular}




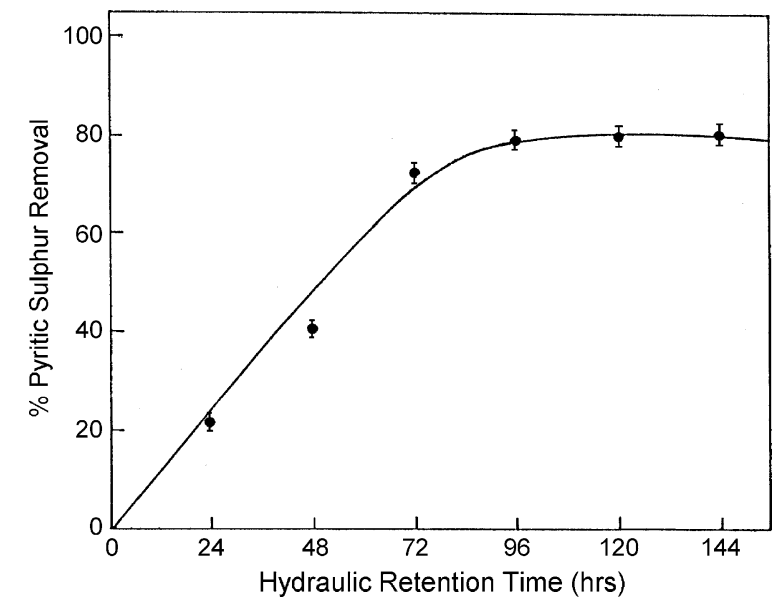

Fig. 2. Performance evaluation of coal slurry reactor at various hydraulic retention times (HRTs).

mixture technology fully justifies the grinding of coal to fine sizes $(45-65 \mu \mathrm{m})$.

\subsection{Assessment of pulp density for maximum removal of sulphur from coal}

The pulp density ranging from 5 to 40 percent was tested for desulphurization at optimal HRT The results obtained are presented in Fig. 3. The pulp density of 15 percent is found to be optimal since the removal efficiency of the pyritic sulphur is found to be maximum. Further increase in the pulp density resulted in decrease of removal efficiency of pyritic sulphur. The lower efficiency of desulphurization at higher pulp density may be attributed to the improper mixing of coal particles in the coal slurry reactor, which results in poor contact between the microorganisms and coal particles. In other words, the reduction in the efficiency of desulphurization at higher pulp density may be due to the reduction in the external surface area available for microbial population to grow and also due to low solubility of carbon dioxide and oxygen at higher pulp density [1]. The high pulp densities of coal particles and low microbial concentration,

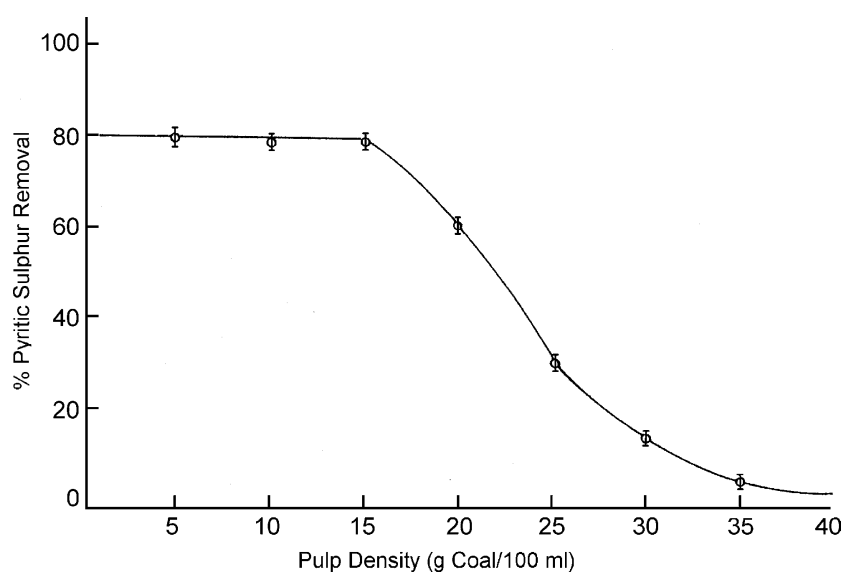

Fig. 3. Efficiency of pyritic sulphur removal in coal slurry reactor at various pulp densities at optimal HRT.

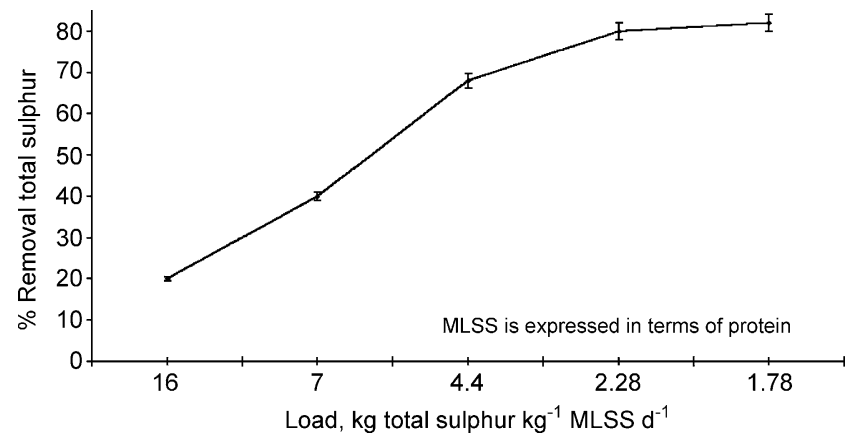

Fig. 4. Removal of total sulphur at different loading at optimal HRT.

rate of desulphurization are limited by the cell concentrations. In the present investigation, at pulp density of 30 percent, most of the pulp was observed to be getting settled in the bioreactor. Practically there was limited mixing of the coal pulp with reactor contents [1].

\subsection{Assessment of sulphur loading at optimal HRT}

The performance of coal slurry reactor at different total sulphur loadings and pyritic sulphur loadings has been presented in the Figs. 4 and 5 respectively. The system could remove the total sulphur ranging from 20 to 82 percent at total sulphur loading range of $1.78-16 \mathrm{~kg}$ total sulphur $\mathrm{kg}^{-1}$ MLSS $\mathrm{d}^{-1}$. Similarly, the pyritic sulphur loadings in the bioreactor system corresponding to total sulphur loads were in the range of $1.1-11.3 \mathrm{~kg}$ pyritic sulphur $\mathrm{kg}^{-1} \mathrm{MLSS} \mathrm{d}^{-1}$. The optimal load for the system was found to be $2.28 \mathrm{~kg}$ total sulphur $\mathrm{kg}^{-1}$ MLSS $\mathrm{d}^{-1}$, while the optimal load in terms of pyritic sulphur was found to be $1.9 \mathrm{~kg}$ pyritic sulphur $\mathrm{kg}^{-1}$ MLSS $\mathrm{d}^{-1}$. The removal efficiency of 79 percent in terms of pyritic sulphur at optimal load could be achieved while the total sulphur removal efficiency at the corresponding total load was found to be 80 percent.

\subsection{Performance of the coal slurry reactor at optimal conditions}

The coal slurry reactor was operated at optimal conditions and the results on the performance of the reactor

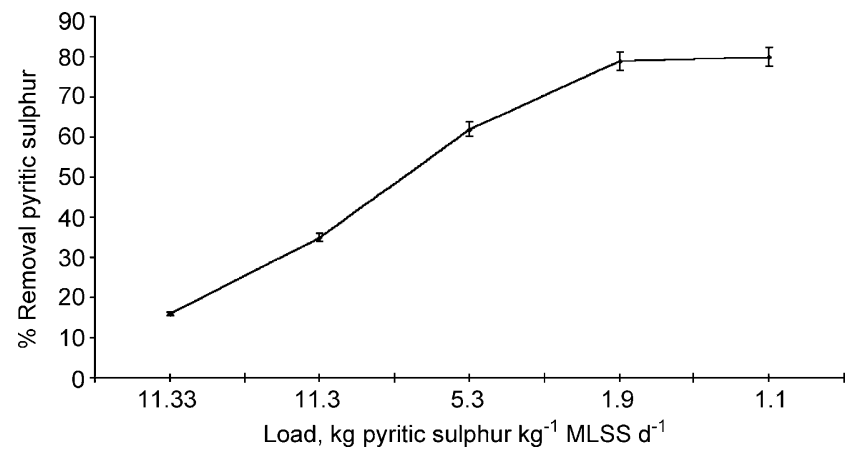

Fig. 5. Removal of pyritic sulphur at different loading at optimal HRT. 
Table 2

Operational parameters of coal slurry reactor for microbial desulphurization of coal containing pyritic sulphur

\begin{tabular}{|c|c|}
\hline Parameters & Magnitude \\
\hline \multicolumn{2}{|l|}{ A. Details of bioreactor system } \\
\hline Working volume of the reactor (1) & 60 \\
\hline Working volume of the settler (1) & 2.5 \\
\hline \multicolumn{2}{|l|}{ B. Operational parameter } \\
\hline $\mathrm{PH}$ & $2.4 \pm 0.2$ \\
\hline Temperature & $32 \pm 2{ }^{\circ} \mathrm{C}$ \\
\hline Feed volume of $1 \mathrm{~d}^{-1}$ nutritional medium & 15 \\
\hline Coal feeding $\left(\mathrm{kg} \mathrm{d}^{-1}\right)$ & 1.5 \\
\hline Coal particle size $(\mu \mathrm{m})$ & $45-65$ \\
\hline Pulp density (g $\left.100 \mathrm{ml}^{-1}\right)$ & 15 \\
\hline $\begin{array}{l}\text { Initial concentration of sulphate in nutritional } \\
\text { medium }\left(\mathrm{g} \mathrm{l}^{-1}\right)\end{array}$ & 1.2 \\
\hline Concentration of sulphate in the overflow of settler $\left(\mathrm{g} \mathrm{l}^{-1}\right)$ & 3.5 \\
\hline Biomass in the reactor $\left(\mathrm{mg} \mathrm{l}^{-1}\right)$ & 351 \\
\hline Substrate loading ( $\mathrm{kg}$ pyritic sulphur $\mathrm{kg}^{-1} \mathrm{MLSS} \mathrm{d}^{-1}$ ) & 1.9 \\
\hline Biomass in the effluent $\left(\mathrm{mg} \mathrm{1}^{-1}\right)$ & 68 \\
\hline Percent volume of the overflow of settler recycled (\%) & 20 \\
\hline HRT (h) & 96 \\
\hline Dissolved Oxygen $\left(\mathrm{mg} \mathrm{l}^{-1}\right)$ & $1.8-2.2$ \\
\hline Treated coal yield $(\%)$ & 72 \\
\hline
\end{tabular}

in terms of treated coal quality and coal yield were assessed. The operational parameters of coal slurry reactor for microbial desulphurization of coal containing pyritic sulphur are presented in Table 2. Results presented in Table 3 shows that the pyritic sulphur presents in the coal forms the feed alongwith nutrients and gets oxidized as sulphate in the bioreactor. Actual production of sulphate from biooxidation of pyrite is computed after estimation of sulphate in the outflow of settler by subtracting the magnitude of sulphate input from ammonium sulphate and $\mathrm{H}_{2} \mathrm{SO}_{4}$ which are supplemented to the nutritional medium.

Table 3

Performance of coal slurry reactor for microbial desulphurization of coal containing pyritic sulphur at optimal condition

\begin{tabular}{|c|c|c|}
\hline \multirow[t]{2}{*}{ Parameters } & \multicolumn{2}{|l|}{ Magnitude } \\
\hline & $\begin{array}{l}\text { Untreated } \\
\text { coal }\end{array}$ & $\begin{array}{l}\text { Treated } \\
\text { coal }\end{array}$ \\
\hline \multicolumn{3}{|l|}{ Proximate characteristics (dry basis) } \\
\hline Moisture (\%) & 7.90 & 6.30 \\
\hline Volatile matter (\%) & 21.86 & 18.72 \\
\hline $\operatorname{Ash}(\%)$ & 31 & 7.44 \\
\hline Fixed carbon $(\%)$ & 39.24 & 67.54 \\
\hline \multicolumn{3}{|l|}{ Sulphur profile analysis } \\
\hline Total sulphur & 3.90 & 0.78 \\
\hline Inorganic sulphate & 0.84 & 0.09 \\
\hline Pyritic sulphur (\%) & 2.80 & 0.59 \\
\hline Organic sulphur $(\%)$ & 0.21 & 0.19 \\
\hline Gross calorific value of the coal $\left(\mathrm{kcal} \mathrm{kg}^{-1}\right)$ & 4400 & 6800 \\
\hline Useful heat value $\left(\mathrm{kcal} \mathrm{kg}^{-1}\right)$ & 3493 & 7009 \\
\hline Total sulphur removal $(\%)$ & & 79.18 \\
\hline Total removal of pyretic sulphur (\%) & & 81.31 \\
\hline Ash removal $(\%)$ & & 76.00 \\
\hline
\end{tabular}

The above values are average of five sets of observations.
However, sulphate production from pyrite and the remaining pyritic sulphur, present in coal, leaves a marginal discrepancy from the pyritic sulphur in the feed coal. Based on the sulphate production and removal of pyritic sulphur from the coal, optimal pulp density and sulphur loading, the efficiency of total sulphur removal is found to be 80 percent at the selected HRT of $96 \mathrm{~h}$. The results in Table 3 show that there is 76 percent reduction in ash content of the treated coal. Further, results of the present study also indicate that the microbial process, using coal slurry reactor system, could remove the pyritic sulphur upto 79 percent with improved energy value of the coal. This is due to dissolution of some of basic mineral matter of the coal in the bioreactor as it operates at an acidic $\mathrm{pH}$. Further, ash removal from the coal may also be attributed to the enzymes produced by the activities of the microorganisms. The attachment of microorganisms to the coal particles containing pyrite is seen in the scanning electron micrograph as presented in Fig. 6. The removal of ash from the coal in microbial processes results in improvement of the coal heating value, as the calorific value of the treated coal increases from 4400 to $6800 \mathrm{kcal} \mathrm{kg}^{-1}$ of coal. The conventional floatation methods result in only 50-60 percent removal of pyritic sulphur with a $40-50$ percent removal of ash with marginal recovery of the energy values of the coal [2]. The yield of treated coal is found to be 72 percent, which is high as compared to the yield observed in the floatation method adopted presently in coal washeries [2].

\subsection{Evaluation of kinetic coefficient for coal slurry reactor}

Efficiency of coal slurry reactor system depends on the kinetics constants such as $Y, K_{\mathrm{d}}, \mu_{\max }$ and $K_{\mathrm{s}}$. These constants give the basic information for engineering design of the nucrobial desulphurization units. The experiments on microbial desulphurization of coal have shown that a useful relationship for design and operation through an expression

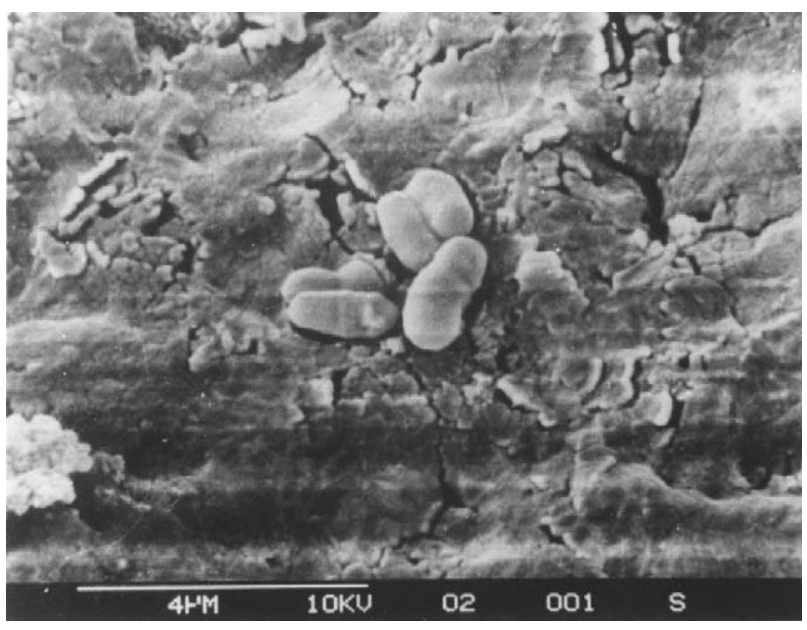

Fig. 6. Scanning electron micrograph of the content of coal slurry reactor showing attachment of Thiobacillus Microorganisms with Coal Particles. 


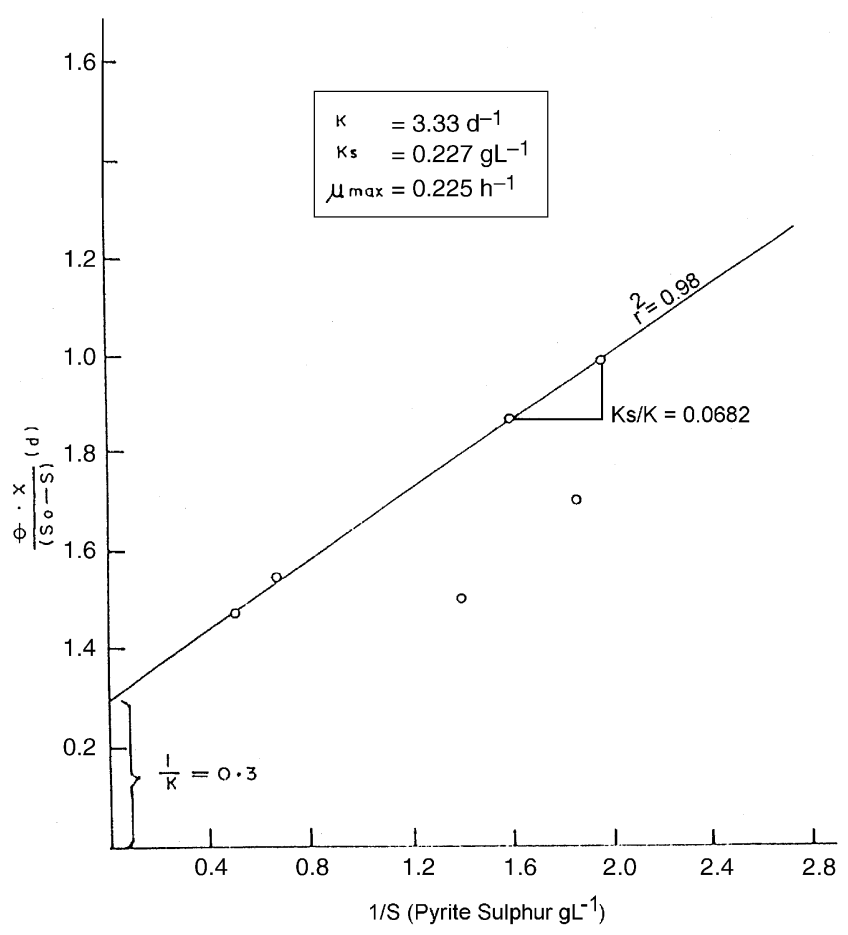

Fig. 7. Evaluation of biokinetic constants ' $K_{\mathrm{s}}$ ' and ' $\mu_{\max }$ ' for microbial desulphurization of coal containing pyritic sulphur in a coal slurry reactor.

relating to microbial growth and pyrite utilization [13].

$1 / \theta c=Y U-K_{\mathrm{d}}$

Thus, by plotting $1 / \theta c$ versus pyrite loadings $(U), Y$ and $K_{\mathrm{d}}$ can be obtained.

Similarly, by applying the Monod equation, one can derive the following relation:

$\theta x / S o-S=K_{s} / K . l / s+1 / k$
Thus, by plotting $\theta x / S o-S$ versus $1 / s$, the value of $K_{\mathrm{s}}$ and $K$ can be obtained. Applying Eqs. (1) and (2), all the values of biological constants have been evaluated as shown in Figs. 7 and 8. In comparison with the present findings, the yield coefficients' for the isolated organisms are low since the production of biomass per unit weight of pyritic sulphur oxidised is very small. However, some discrepancies in the estimation of biomass are observed, as it is based on indirect estimation of protein. The microbial growth rate $\mu_{\max }$ has been reported to be in the range of 0.0091 $-0.0733 \mathrm{~h}^{-1}$, based on pyritic sulphur in coal $[18,19]$. The value observed $\left(0.025 \mathrm{~h}^{-1}\right)$, in the present investigation, falls in the above range. The variation in the biokinetics may be attributed to the difference in physiological pattern of growth among the strains of Thiobacillus, characteristics of pyrite and coal, and bioreactor systems used in the process of biodesulphurization. The value of half saturation rate constant $\left(K_{\mathrm{s}}\right)$ reported in the literature is well in agreement with the value observed in the present investigation.

\section{Conclusions}

- The coal containing total sulphur of $3.90 \mathrm{wt} \%$ having pyritic sulphur content of $2.80 \mathrm{wt} \%$ could be desulphurized, in a coal slurry reactor, to the extent of $80 \%$ with reference to total sulphur removal. The pyritic sulphur removal could be achieved to the extent of $79 \%$, while ash removal was found to be $76 \%$ at optimal condition.

- At optimal conditions, the coal slurry was operated at $15 \%$ pulp density with a total sulphur load of $2.28 \mathrm{~kg}$ total sulphur $\mathrm{kg}^{-1} \mathrm{MLSS} \mathrm{d}^{-1}$, while the optimal load in terms of pyritic sulphur was $1.9 \mathrm{~kg}$ pyritic sulphur $\mathrm{kg}^{-1}$ MLSS $\mathrm{d}^{-1}$ with a HRT of $96 \mathrm{~h}$.

- The kinetic coefficients, viz. yield coefficient $(Y=0.178)$, decay coefficient $\left(K_{\mathrm{d}}=0.007 \mathrm{~d}^{-1}\right)$, Maximum growth

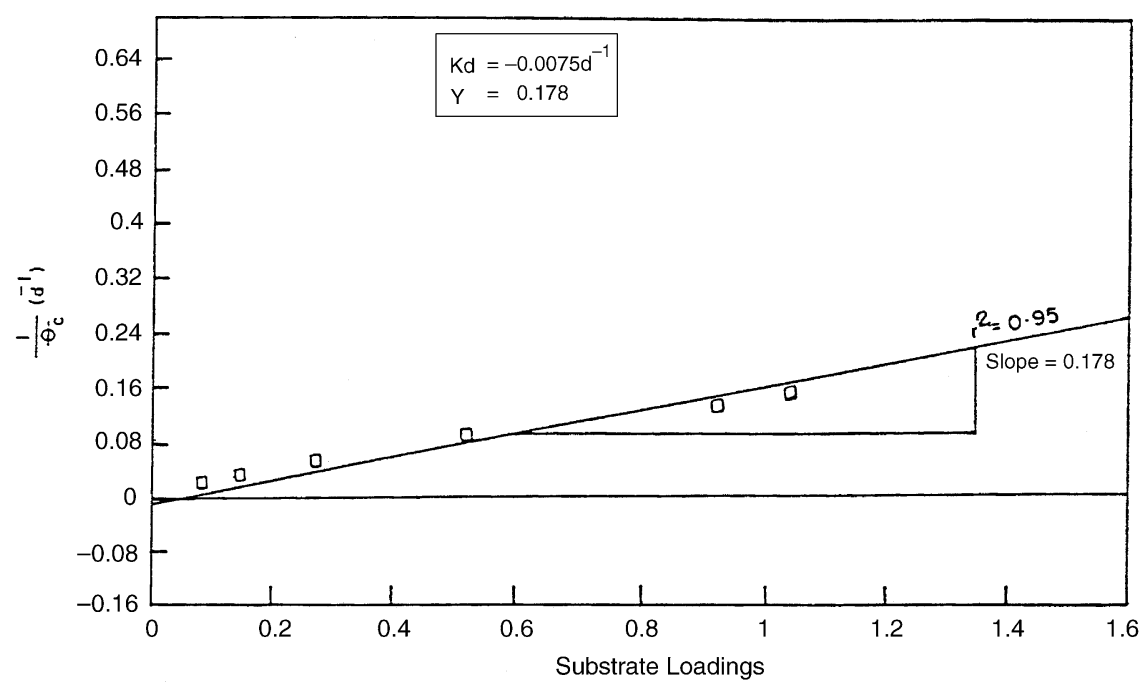

Fig. 8. Evaluation of biokinetic constants ' $Y$ ' and ' $K_{\mathrm{d}}$ ' for microbial desulphurization of coal containing pyritic sulphur in a coal Sl. 
rate $\left(\mu_{\max }=0.025 \mathrm{~h}^{-1}\right)$ and half saturation rate constant $\left(K_{\mathrm{s}}=0.220 \mathrm{~g} \mathrm{l}^{-1}\right)$ were computed for the system.

\section{Acknowledgements}

The authors are thankful to Director, NEERI for his permission to publish the work. The authors are also grateful to Ex-Director, Prof P. Khanna for his guidance during the experimentation. Authors are also thankful to Department of Biotechnology, Ministry of Science and Technology, Govt of India, New Delhi for providing financial support. Co-operation of our colleagues from Instrumentation, Workshop, and Environmental Biotechnology Division of the Institute is earnestly acknowledged.

\section{References}

[1] Andrews GF, Stevens CJ, Dugan PR. In Proceedings of the Second International Symposium on Biological Processing of Coal. EPRI GS 1991;7482:310.

[2] Monticello DJ, Firnerty WR. Ann Rev Microbiol 1985;39:317.
[3] Cara J, Aller E, Gomez AI, Carcia ME. Ingenieria Quimica 2002;386:237.

[4] Chang YC, Myerson AS. Biotechnol Bioeng 1982;24:889.

[5] Ferris DD, Harrison KE. In: Dugan PR, Quiley DR, Attia A, editors. In Processing and utilisation of high sulphur coal IV. New York: Elsevier; 1991. p. 325.

[6] Cara J, Aller A, Otero M, Moran A. Appl Microbiol Biotechnol 2001; 55:49.

[7] Raman VK, Pandey RA, Bal AS, Critical CRC. Reviews in Environmental Science and Technology 1995;25:291.

[8] Detz CM, Barvinchak G. Min Cong J 1979;65:75.

[9] Bos P, Huber TF, Luyben K, Ch AM, Kuenen JG. Res Conserv Recycl 1988;1:279.

[10] Kargi F, Cervoni TD. Biotechnol Lett 1983;5:33.

[11] Tillet DM, Myersen AS. Biotechnol Bioeng 1987;24:146.

[12] Indian Standard Methods of test for coal and coke. Bureau of Indian Standards, Manak Bhavan, New Delhi; 1984. IS: 1350.

[13] V.K. Raman. Bioxidative removal of pyritic sulphur from coal School of Environmental Biology. PhD Thesis. A.P.S. University, Rewa, MP, India; 1993.

[14] Kargi F, Weissman JG. Biotechnol Bioeng 1984;26:241.

[15] Oison GJ, Kelly RM. Resour Conserv Recycl 1991;5:211.

[16] Cara J, Moran A, Carballo T, Rozada F, Aller A. Fuel 2003; 82: 2065.

[17] Myerson AS, Kline PC. Biotechnol Bioengg 1984;26:604.

[18] Hoffmann R, Faust BC, Panda FA, Koo HH, Tsuchiya HM. Appl Environ Microbiol 1981;42:256.

[19] Myersen AS, Kline PC. Biotechnol Bioeng 1984;26:92. 